çalışma konuları bulanabilecek bu kitap genç Osmanlı tarihçileri için bir başucu kitabı olarak düşünülmekte ve tarih severlerin beğenisini hak etmektedir.

25 Kasım 2016’da kaybettiğimiz Yavuz Selim Karakışla’yı rahmetle yâd ediyoruz.

Duygu Tanıdı

Eskişehir Osmangazi Üniversitesi

Khaled el-Rouayheb,

\title{
Islamic Intellectual History in the Seventeenth Century: Scholarly Currents in the Ottoman Empire and the Maghreb,
}

New York: Cambridge University Press, 2015. xvi + 399 pp., ISBN 978-110-7042-96-4.

In this ambitious and extensive project, Khaled el-Rouayheb aims to destroy the historiographical biases that belittle the value of early modern intellectual history in the Islamic world. Ironically, multiple perspectives have rendered derogatory verdicts on the legacy of the early modern period -perspectives that have otherwise been extensively challenged in fields other than intellectual history. In the case of historians of the Ottoman Empire, the intellectual figures of the sixteenth century still represent the pinnacle of Ottoman greatness, followed by decline in subsequent centuries (with allowance for perhaps a few "exceptional" cases, such as Katib Çelebi). In the case of Arabists, the view is even more dismal, for the period from the collapse of the 'Abbasids up until the revival of Arabic language and literature in the nineteenth century is viewed as a period of uninterrupted stagnation and decline. And finally, in the case of Islamist perspectives, the early modern period is viewed as a period marked only by taqlid or "imitation," mixed with crude forms of Sufism and idolatrous or syncretic practices that corrupted the original foundations of Islam.

Challenging this conventional wisdom is further complicated by the dense, technical, and sometimes lengthy nature of the sources, which often took the form of commentaries or "glosses" on older works from an earlier period. When combined with the biases of modern scholars toward an anti-elitist historiography 
that seeks to narrate from the perspective of a broader range of people, the result has been a lack of awareness, and even disparagement of the high intellectual traditions of the period. This state of affairs, argues el-Rouayheb, creates serious problems in its own right, as early modern Europe is regularly associated with the emergence of major intellectual figures, whereas in the Islamic world, nonspecialists might come away with the idea that this was a realm reserved only for popular chroniclers, Sufi diarists, or those interested in occult knowledge (3). And furthermore, attempts to articulate questions about a comparative, global intellectual history cannot even be asked without laying the proper groundwork that would allow Islamic intellectual history to be taken on its own terms (8-9).

What follows is an intellectual history tour de force, and this short review cannot do justice to all the elements that make up the book. However, to begin, one basic observation is in order, which is that the title of the book is misleading in terms of periodization. While key seventeenth century figures obviously receive extensive treatment in the work, this is really an intellectual history of the Islamic world from the post-Mongol period up into the twentieth century, once we factor in the extensive discussion of the sources on which these authors drew, and the ultimate impact of their works in the centuries that followed. Any scholar with interests in the intellectual history of the Islamic world, regardless of their time frame, should therefore read this work and engage with the historical intervention that it represents.

The book is divided into three parts, each of which comes close to representing a full-length study in its own right. The first part takes aim at a foundational thesis in Ottoman history, which was that anti-intellectual trends dating from the end of the sixteenth century and the rise of the so-called "Kadizadeli movement" snuffed out the vitality of intellectual life and the rational sciences among Ottoman thinkers. This generalization is based on the use of a few key sources, and el-Rouayheb argues that when these sources are juxtaposed against the broader record of the period, a very different picture emerges that renders this view unsustainable. Even leaving aside the point that Kadizadeli-inspired activists were probably a minority in Ottoman society, he shows that many of these figures did not reject the rational sciences or theology, and furthermore, for every contemporary source like Katib Çelebi who bemoaned the decline of these disciplines, there were many others who instead complained of an overabundance of thinkers pursuing these vocations at the expense of what they thought was more important. 
As a result, the idea of a "triumph of fanaticism" and intellectual decline across all fields is not a compelling vision for the dynamics of the period (26).

El-Rouayheb replaces this trope with a narrative of how a network of Kurdish and Azeri scholars came to transmit the Timurid Persian intellectual tradition represented by thinkers such as Jalāl al-Dīn al-Dawānī (d. 1502) and 'Isām al-Dīn Isfarāyinī (d. 1537). While these thinkers were not unknown to the sixteenth-century Ottoman intellectual tradition, el-Rouayheb argues that their full integration into Ottoman intellectual life only took place as Kurdish and Azeri scholars fleeing the Safavid conquest of their borderlands in the early seventeenth century moved into Ottoman centers in the eastern part of the empire, and began to train Ottoman students. This can be seen in the intellectual genealogies laid out by various Ottoman scholars of the eighteenth century once this transmission had fully run its course, and interestingly, it came to almost completely replace any reliance on the founding generation of Ottoman scholarly figures such as Kemalpaşazade, Molla Fenārī, or Ebusüud Efendi (43-44).

What set this movement apart from previous Ottoman generations was its intensive employment of an "ethos of verification" (tahqiq) that demanded a fuller intellectual engagement with, and critique of the received wisdom of the past. This was bound up with the science of dialetics and "rules of enquiry" ( $\bar{a} d \bar{a} b$ $a l-b a h t h)$, and a related rise of what el-Rouayheb calls "deep reading," or rules for the careful perusal of scholarly works (ādāb al-mutāla'a). Interestingly, this tradition did not extend in similar fashion into the Indian Subcontinent, Egypt, North Africa, or most ironically of all, Iran, until after the period had run its course. As a result, scholars encountering the modes of logical argumentation that these thinkers developed in the Ottoman context often remarked on their strangeness and novelty (66-70). Perhaps the most engaging chapter examines the work of the Ottoman thinkers Müneccimbāşī (d. 1702) and Sāçaklīzāde (d. 1716). The former was one of the first Muslim scholars to extensively outline the strategies for "deep reading," and el-Rouayheb argues that his work represented a move away from the traditional oral-aural networks for teaching and transmitting scholarship in the pre-modern Islamic world in favor of extensive engagement with written works. Interestingly, Sāçaklīzāde may have espoused the method in part due to his growing distrust of many of the teachers of his own era, perhaps hoping to instill in his readers different strategies or approaches to various topical issues. El-Rouayheb suggests that licensing requirements for taking posts in 
the Ottoman educational and scholarly system may have driven this change, for often the small number of people granting the licensing were not the same people who actually instructed those pursuing the posts. Therefore, one required the broadest possible access to sources of knowledge in order to stand out among the competitors for these posts (126-7).

The second part of the work shifts the focus away from the core Ottoman lands to the intersection between North African scholars and the Ottoman province of Egypt. Here, el-Rouayheb argues for a parallel process of scholarly traditions from outside of the Ottoman context coming to deeply influence the intellectual trajectory of Egypt. Here, a key figure is the Maghrebì scholar Muhammad b. Yūsuf al-Sanūsī (d. 1490) and his intellectual descendants. El-Rouayheb argues that rather than viewing theology (kaläm) as a dead or discouraged discipline after its development in the medieval period, suitable only for combating heresies, we should instead view the early modern intellectual history of North Africa and Egypt as bound up with the revival of rational theology (173-5). AlSanūsī and his followers were no supporters of blind imitation; in fact, al-Sanūsī went as far as to require a basic knowledge of the rational underpinnings of the key principles of Islam as a duty incumbent on all Muslims, even if they could not be expected to master all of the intricacies, and declared taqlid as tantamount to unbelief. As a result, he penned a number of works aimed at all levels of society, from the simple common believer all the way up to the most advanced student of logic and theology (184). In fact, his intellectual descendant Hasan al-Yūsī (d. 1691), an influential transmitter of al-Sanūsìs works, was forced to soften his predecessor's uncompromising demand for rational understanding at all levels of society when some of his rural followers began to harass the common folk for having what they deemed as an insufficient understanding of the tenets of their religious faith (204-6). Al-Sanūsìs works, along with those of his commentators, spread throughout the Maghreb from the sixteenth century onward, and eventually various intellectual descendants began to migrate to Egypt in the seventeenth century, thereby establishing his intellectual tradition there.

Interestingly, the Perso-Kurdish-Azeri tradition and the Maghrebī tradition tended to remain confined to their separate areas, and there is only limited evidence for their adoption across this intellectual boundary. While elements of alSanūsīs ideas are echoed in some of the tracts of the Kadizadeli movement (1913 ), and scholars representing the two separate wings of the movement sometimes 
exchanged views or clashed over ideas in Mecca and Medina, el-Rouayheb suggests that the gaps between the Hanafi-Maturidi and Ash'arī legal cultures espoused by the two regions proved decisive in limiting their appeal across those boundaries (143). Nevertheless, by the end of the eighteenth century, the ideas of al-Sanūsì had become so entrenched that anti-rationalist critics like al-Zābidī (d. 1791) complained bitterly at their prominence, and these works were later lithographed and widely distributed among the madrasa students in Egypt well into the twentieth century. In fact, even early twentieth-century revivalists like Muhammad 'Abduh inadvertently displayed their debt to al-Sanūsîs thought in his writings in his denunciation of taqlid, even as he sought to write off the entire development of medieval and early modern thought as deficient (202).

The third and final part of the work takes up the changes in Sufi intellectual culture over the course of the early modern period. The Sufi thinkers under consideration here defined "verification" differently from the thinkers of the earlier sections, viewing it instead as mystical-experiential authentication of truths that logicians or ordinary believers would assent to only in the abstract sense. But the key change from the seventeenth century onward was the growing support throughout much of the Islamic world for the theory of the "unity of existence" (wahdat al-wujüd) pioneered by the Anatolian and Persian followers of Ibn al'Arabī (d. 1240). A thorough evaluation of the works of various Sufi thinkers prior to the seventeenth century in Egypt and the Arabic-speaking world more broadly shows that almost none of them engaged Ibn al-'Arabī's most controversial work Fusüs al-hikam, and instead confined themselves entirely to his Futuhät works. Even then, they usually enjoined extreme caution in engaging with these advanced mystical works, with one Hadramī scholar going as far as having his only copy of the Futuhät al-Makkiya burnt upon his death because he feared it might corrupt others (241). As with the first two parts of the book, el-Rouayheb locates the impetus for change in an influx of migrants into the region, in the form of the Shattāin order from the Indian Subcontinent, the Naqshbandī order from Central Asia (which should be distinguished from its later Mujaddadī branches), and the Khalwatī order from Azerbaijan. The representatives of all three of these orders were deeply steeped in the philosophy of wahdat al-wujüd, and as they began to settle in the Holy Cities, the Levant, and Egypt, they spread their ideas and defense of their position far and wide, with the result being that by the eighteenth century, their representatives were being appointed as heads of 
al-Azhar, and by end of the nineteenth century, their thought had spread as far afield as sub-Saharan Africa (268).

This influx of Sufi philosophical thought had some unintended consequences. In wrestling with the question of why the prominent monist Sufi Ibrāhim alKūrānī (d. 1690) made connections with a number of prominent Hanbalī thinkers in the seventeenth century, el-Rouayheb finds that the viewpoints expressed in al-Kūrānīs defense of Ibn al-'Arabī’s thought accorded more with Hanbalī positions than those of his North African Ash arī opponents. This led to an ironic intersection whereby a prominent Sufi monist thinker may have played a role in rehabilitating some of the thought of Hanbali thinkers who later formed a foundation for Salafi and Wahhabi descendants, who now find themselves baffled by the connections between them, given their subsequent hostility to many Sufi ideas (264-5). Al-Kūrānī utilized these ideas to challenge earlier scholarly figures such as the medieval scholar Sa'd al-Dīn al-Taftazānī (d. 1390), who had rejected the theory of wahdat al-wujüd as the misguided ideas of "pseudo-Sufis" (316-7), and was often utilized by monist opponents as a primary argument against monism's growing appeal. Interestingly, al-Kūrānīs notable contemporary 'Abd al-Ghānī al-Nābulūsī (d. 1723) took issue with al-Kūrānī’s argument as violating the rules of Ash 'arite occasionalism, and instead argued for different approaches to defending the monist position. But el-Rouayheb ultimately concludes by pointing out that neither thinker accords with the "neo-Sufi" theory, which holds Sufis of the early modern period increasingly abandoned monism and "quietism" in favor of a growing "orthodoxy" and "activism." Instead, the wahdat al-wujüd tradition only grew stronger over the course of the period, meaning that the "new Sufism" was in fact very much an extension of the old one (306).

The author concludes by reiterating his call for a rejection of the ideological currents of the twentieth century which have obscured the vitality of Islamic intellectual culture in the centuries that preceded it. The further establishment of the narratives of intellectual culture of this period can then be linked to the growing revisionist understandings of the historical context of the Islamic world -a task that el-Rouayheb purposely does not address at the present juncture, in part because the overall picture remains disputed and murky on all fronts (352-3). Just as Western medievalists eventually overturned their own ideological portrayals of Renaissance and Enlightenment condemnations of the medieval past as a "dark age," so must scholars of the Islamic world move beyond the ideological 
blinders of their own contemporary age in favor of a more dispassionate account of what really took place (361).

El-Rouayheb has produced a fascinating work that presents the early modern period as one of great intellectual vitality, with ideas and intellectual movements swirling from Morocco to Indonesia. He introduces us to a wide variety of figures, many of whom have been lost to history for all but the most determined of scholarly researchers. One hopes, as the author implies by the end of his study, that future research will allow for a better understanding of the implications of the stories sketched out here. In fact, this reviewer might take a contrary view, in that the work el-Rouayheb has initiated might well begin allowing for the comparative work that has so far proven unfruitful or forced, and perhaps we should not abandon the comparative frame to some undetermined point in the future. For example, Dengiian Jin's recent work on the emergence of scientific thought argues that the development of a sustained form of skepticism of past authorities and inherited traditions was what set a small number of Europeans apart from other peoples around the world in developing the scientific method. ${ }^{1}$ However, a full reading of el-Rouayheb's work also demonstrates a good deal of skepticism of established schools, authorities, and past traditions among Muslim thinkers in a contemporary period. To ask but one potential question of this potential overlap: can we now compare the role of skepticism in the development of various intellectual traditions of the early modern period?

A few complaints might be registered, though none detract from the value of the book. The discussion of the development of logic in the a da a b al-bahth tradition in the second may require some additional contextualization, as this reviewer, unfamiliar with the genre, found it difficult to fully understand how the works under discussion represented important intellectual advances in the broader context of intellectual history, even after multiple readings. This suggests more support for the uninitiated may be in order. Also, the litany discussed on p. 269 should probably be rendered as the noted Khalwati ritual prayer of the wird al-sattār, given that it was passed down through the Şa 'bānì branch of the order, not wird al-sahar as rendered in the text.

John J. Curry

University of Nevada, Las Vegas

1 Dengjian Jin, The Great Knowledge Transcendence: The Rise of Western Science and Technology Reframed (New York: Palgrave Macmillan, 2016). 